University of Nebraska - Lincoln

DigitalCommons@University of Nebraska - Lincoln

Faculty Publications: Department of Entomology

Entomology, Department of

1995

\title{
Characterization of General Esterases in Workers of the Eastern Subterranean Termite (Isoptera: Rhinotermitidae)
}

\author{
Robert W. Davis \\ University of Nebraska-Lincoln \\ Shripat T. Kamble \\ Universitiy of Nebraska--Lincoln, skamble1@unl.edu \\ Suresh K. Prabhakaran \\ University of Nebraska-Lincoln
}

Follow this and additional works at: https://digitalcommons.unl.edu/entomologyfacpub

Part of the Entomology Commons

Davis, Robert W.; Kamble, Shripat T.; and Prabhakaran, Suresh K., "Characterization of General Esterases in Workers of the Eastern Subterranean Termite (Isoptera: Rhinotermitidae)" (1995). Faculty Publications: Department of Entomology. 309.

https://digitalcommons.unl.edu/entomologyfacpub/309

This Article is brought to you for free and open access by the Entomology, Department of at DigitalCommons@University of Nebraska - Lincoln. It has been accepted for inclusion in Faculty Publications: Department of Entomology by an authorized administrator of DigitalCommons@University of Nebraska - Lincoln. 


\title{
Characterization of General Esterases in Workers of the Eastern Subterranean Termite (Isoptera: Rhinotermitidae)
}

\author{
ROBERT W. DAVIS, SHRIPAT T. KAMBLE, AND SURESH K. PRABHAKARAN \\ Department of Entomology and Water Center/Environmental Programs, University of Nebraska,
} Lincoln, NE 68583-0816

\begin{abstract}
J. Econ. Entomol. 88(3): 574-578 (1995)
ABSTRACT General esterases from eastern subterranean termite, Reticulitermes flavipes (Kollar), workers were examined for activity and were characterized by electrophoretic and biochemical methods. Greater activity was observed toward $\alpha$-naphthyl substrates when compared with $\rho$-nitrophenyl substrates. The specific activity of the esterases increased with a corresponding increase in $\alpha$-naphthyl acetate concentration. Maximal activities were observed with a buffer $\mathrm{pH}$ of 7.6 and an incubation temperature of $45^{\circ} \mathrm{C}$. The calculated MichaelisMenten constant $\left(\mathrm{K}_{\mathrm{m}}\right)$ was $72.53 \mu \mathrm{M}$ and the $\mathrm{V}_{\text {max }}$ was $33.77 \mu \mathrm{M} / \mathrm{min} / \mathrm{mg}$ of protein. Nondenaturing polyacrylamide gel electrophoresis revealed the presence of seven esterase bands, which were named E1-E7. Bands E1-E4 (slowest gel mobility) were determined to be cholinesterases based on physostigmine inhibition. The remaining three bands were identified as carboxylesterases based on inhibition by paraoxon. The molecular weights of the seven bands ranged from 71.5 to $97.2 \mathrm{kD}$.
\end{abstract}

KEY WORDS Reticulitermes flavipes, esterase, termites

SUBTERRANEAN TERMITES CAUSE considerable damage to structures and wood products. An estimated $\$ 1.17$ billion was spent in 1982 on termite prevention and control measures in the United States (Granovsky 1983). The eastern subterranean termite, Reticulitermes flavipes (Kollar), is one of the most economically important species in the United States (Mampe 1982). Kamble et al. (1984) estimated that a minimum of $\$ 1$ million is spent annually in Nebraska as a result of damage caused by Reticulitermes spp.

Despite the economic importance of subterranean termites, little is known about the metabolic and xenobiotic detoxifying systems of these insects. Esterases are important in the metabolism and physiology of animals and plants (Sivakumaran \& Mayo 1991). These enzymes may hydrolyze endogenous substances, assume a part in intermediary metabolism, or promote xenobiotic detoxification (Shen \& Dowd 1991). Esterases are proteins that are defined by their ability to catalyze the hydrolysis of ester bonds within lipophilic compounds (Pantelouris \& Amason 1966). They are primarily phase I enzymes which, in the presence of water, cleave the target compound into an alcohol and an acid. The ability of esterases to hydrolyze synthetic amides and esters is well documented (Eto 1974, Dauterman 1976, Junge 1984, Junge \& Kless 1984, Wilkinson 1985).

The hydrolases include the following esterases: arylesterases (A esterases, EC 3.1.1.2), carboxylesterases (B esterases, EC 3.1.1.1), and cholinester- ases (B esterases, EC 3.1.1.8) (Augustinson 1959, 1961). Carboxylesterases and cholinesterases are inhibited stoichiometrically by organophosphorois or sulfhydryl reagents without concurrent hydrolysis (Aldridge 1953, Krisch 1971). The arylesterases are resistant to inhibition by OP and SH compounds (Ahmad et al. 1986). Cholinesterase is inhibited by the methylcarbamate, physostigmine (eserine) (Beranek 1974).

Because of the importance of esterases in plysiology, metabolism, and xenobiotic detoxification in insects, we characterized and differentiated termite esterase activity with spectrophotometric and electrophoretic procedures. Our objectives were to determine the esterase banding patterns and to biochemically characterize the general esterases of worker termites.

\section{Materials and Methods}

Termite Collection. Laboratory colonies were initiated with termites collected from rural shelterbelts located in Franklin County, Nebraska. Wood and soil infested with termites were gathered along the surface from the shelterbelts and transported to the laboratory at the University of Nebraska-Lincoln. The termites were reared as described by Davis \& Kamble (1994). The termites were identified as the eastern subterranean termite, $R$. flavipes, based on soldier characteristics (Wheeler \& Wheeler 1963). The termite colonies were maintained for $\approx 18$ months in the laboratory before use in our study. 
Chemicals. Electrophoresis reagents were purchased from Bio-Rad (Hercules, CA). Physostigmine, paraxon (90\%), and $\alpha$-naphthyl acetate were obtained from Sigma (St. Louis, MO).

Preparation of Enzymes. Fifty undifferentiated third and fourth instar termite workers were homogenized using a Tissue Tearer (Biospec Products, Bartlesville, OK) in $3 \mathrm{ml}$ of $0.02 \mathrm{M}$ sodium phosphate buffer ( $\mathrm{pH}$ 7.0). The homogenate was centrifuged at $4^{\circ} \mathrm{C}$ for $20 \mathrm{~min}$ at $10,000 \times \mathrm{g}$ and the restiltant supernatant was used as the enzyme source.

Protein and Esterase Determination. The total protein concentration of the enzyme preparation was determined by the method of Bradford (1976). Total esterase activity toward $\rho$-nitrophenyl acetate, $\rho$-nitrophenyl propionate, and $\rho$-nitrophenyl butyrate was measured as described by Townson (1972). The method of van Asperen (1962) was used to quantify the total esterase activity toward the substrates $\alpha$-naphthyl acetate, $\alpha$ naphthyl propionate, and $\alpha$-naphthyl butyrate by measuring the production of $\alpha$-naphthol. The reaction mixture $(1 \mathrm{ml})$ consisted of enzyme sample $(0.2 \mathrm{mM} \alpha$-naphthyl compounds or $1 \mathrm{mM} \rho$-nitrophenyl compounds) and $0.02 \mathrm{M}$ sodium phosphate buffer $(\mathrm{pH} 7.0)$. The reactions were initiated by adding substrate. The mixture was incubated at $26^{\circ} \mathrm{C}$.

The $\alpha$-naphthol producing reaction was stopped after $15 \mathrm{~min}$ and color was developed by the addition of $166 \mu$ l diazo blue B $(0.3 \%$ in $3.5 \%$ sodium lauryl sulfate). $A_{605}$ was read 10 min later against an enzyme blank using a Spectronic 601 spectrophotometer (Milton Roy, Rochester, NY), and the concentration of hydrolyzed substrate was determined from a standard curve of $\alpha$-naphthol.

The $\rho$-nitrophenol producing reaction rates for each substrate were measured over the first $15 \mathrm{~min}$ by monitoring the change in absorbance at 405 nim. The reaction rates were calculated from a $\rho$ nitrophenol standard curve and corrected for spontaneous hydrolysis of the $\rho$-nitrophenyl substrates.

The effect of temperature on esterase activity was determined by incubating the enzyme at 20 $60^{\circ} \mathrm{C}$ in $5^{\circ} \mathrm{C}$ increments. Sodium phosphate buffers with a pH ranging from 6.0 to 8.0 were used to determine $\mathrm{pH}$ effects on esterase activity. The substrate $\alpha$-naphthyl acetate was used in the temperature and $\mathrm{pH}$ experiments. All enzyme assays were replicated using three different preparations with three determinations for each preparation. The maximum reaction velocity $\left(\mathrm{V}_{\text {max }}\right)$ and the Michaelis-Menten constant $\left(K_{m}\right)$ were determined from a Lineweaver-Burk plot, which was constructed based on the linear regression analysis of $1 /$ (reaction velocity) versus $1 /(\alpha$-naphthyl acetate concentrations) (Lineweaver \& Burk 1934).

Electrophoresis. Nondenaturing native polyacrylamide gel electrophoresis (PAGE) was done in a Bio-Rad vertical electrophoresis unit by using a $9.0 \%$ polyacrylamide separating gel $(7 \mathrm{~cm}), 4.8 \%$

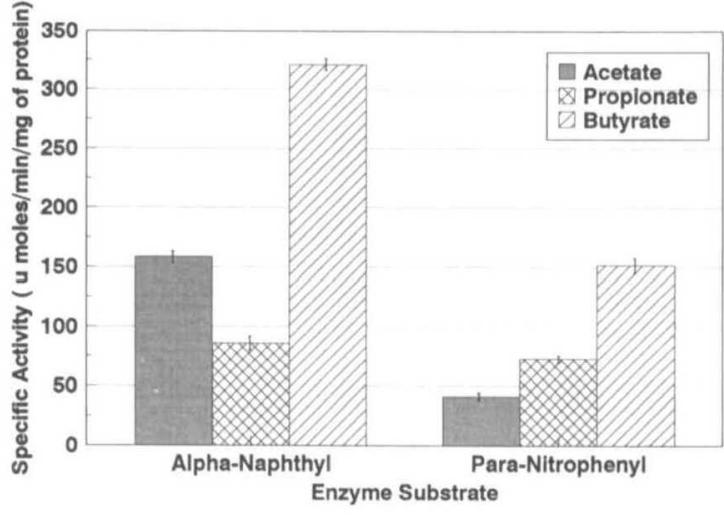

Fig. 1. Specific activities of $R$. flavipes workers gencral esterases toward selected substrates. Each bar represents the mean of three determinations from three preparations each.

stacking gel $(2 \mathrm{~cm})$, and tris-glycine buffer. Each sample $(20 \mu$ l of protein) was loaded with $10 \%$ glycerol (wt:vol) and diluted 1:1 with running buffer. Bromophenol blue $(0.1 \%)$ was used as a marker dye for each gel. Electrophoresis was conducted at a constant $200 \mathrm{~V}$. The gels were stained for esterase activity in $100 \mathrm{ml}$ of $0.1 \mathrm{M}$ phosphate buffer (pH 6.5) containing $2 \% \alpha$-naphthyl acetate and $0.04 \mathrm{~g}$ fast blue BB salt at $25^{\circ} \mathrm{C}$ for 1 . h (Prabhakaran \& Kamble 1993). The gels were then transferred to $7 \%$ acetic acid for storage.

Esterase Characterization. The carboxylesterase and cholinesterase bands on the polyacrylamide gels were identified by incubation with the inhibitors paraoxon and physostigmine (Sivakumaran \& Mayo 1991). Esterase characterization was replicated at least six times.

Molecular Weight Determinations. The molecular weights of the general esterases were estimated as described by Bryan (1977) and Davis (1964). Nondenatured protein molecular weight markers (Sigma) were separated on a set of gels of different polyacrylamide concentrations on a BioRad tube gel electrophoresis unit. For each protein, the $100 \log \left(R_{f} \times 100\right)$ was plotted against the percentage of gel concentration and the slopes (retardation coefficients $\left[K_{\mathrm{H}}\right]$ ) were individually determined. The logarithm of negative $K_{\mathrm{R}}$ was plotted against the molecular weight for each protein to determine a linear curve. The resultant standard curve was used to calculate the molecular weight of each esterase band separated from the homogenate of termite workers.

\section{Results and Discussion}

Enzyme Activity. Spectrophotometric analysis indicated that the termite worker esterases generally exhibited greater specific activity toward the $\alpha$-naphthyl substrates then the $\rho$-nitrophenyl substrates (Fig. 1). Greater specific activity was observed toward four carbon ester sidechains (buty- 


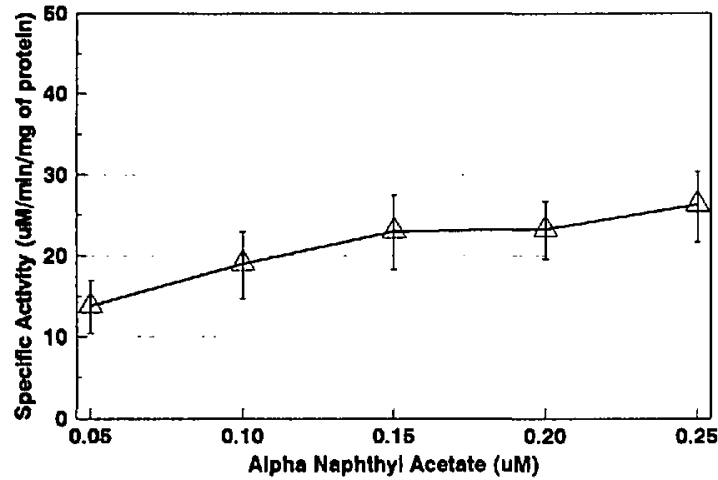

Fig. 2. General esterase activity from $R$ flavipes workers at selected $\alpha$-naphthyl acetate concentrations (buffer pH 7.2). Each point represents the mean \pm SEM of nine determinations.

rate) of both the $\alpha$-naphthyl and $\rho$-nitrophenyl substrates. Similar results were noted from Blattella germanica (L.) (Siegfried \& Scott 1992), Myzus persicae (Sulzer), and Myzus nicotianae Blackman (Abdel-Aal et al. 1990), in which the optimum substrates used were either $\alpha$-naphthyl propionate or $\alpha$-naphthyl butyrate. Ono et al. (1994) found that greenbug, Schizaphis graminum (Rondani), esterases exhibited greater specific activity toward the $\alpha$-naphthyl esters with side chain lengths of $<6$ carbons. For the termite worker homogenate, we observed the greatest specific activity toward $\alpha^{-}$ naphthyl butyrate.

The specific activity of the general esterases toward $\alpha$-naphthyl acetate within the range of 0.05 $0.25 \mu \mathrm{M}$ increased with increasing substrate concentration. The largest specific activity was observed with $0.25 \mu \mathrm{M}$ of $\alpha$-naphthyl acetate $\left(25^{\circ} \mathrm{C}, \mathrm{pH} 7.2\right)$ (Fig. 2). Decreasing specific activities were observed at the lower substrate concentrations. These data agree with the increase in specific activity observed with German cockroach esterases with corresponding increases in substrate concentrations (Prabhakaran \& Kamble 1993). The calculated $K_{\mathrm{m}}$ and $\mathrm{V}_{\max }$ values for the general esterases of the worker termites were calculated as $72.53 \mu \mathrm{M}$ and $33.77 \mu \mathrm{M} / \mathrm{min} / \mathrm{mg}$ of protein, respectively (Fig. 3).

Effect of pH. Esterase specific activity toward $\alpha$-naphthyl acetate varied greatly with changes in $\mathrm{pH}$ (Fig. 4A). Specific activities increased as the $\mathrm{pH}$ increased from 6.0 to 7.6. Maximum specific activity (30.6 $\mu \mathrm{moles} / \mathrm{min} / \mathrm{mg}$ of protein) was observed at $\mathrm{pH}$ 7.6. Sharply lower specific activities were observed at $\mathrm{pH} 7.8$ and $8.0(5.7$ and 5.5 $\mu \mathrm{M} / \mathrm{min} / \mathrm{mg}$ of protein, respectively). Similarly, Blattella germanica (Prabhakaran \& Kamble 1993) and Schizaphis graminum (Ono et al. 1994) esterases exhibited maximum activity at $\approx 7.6-8.0 \mathrm{pH}$, with decreases observed at lower and higher buffer $\mathrm{pH}$ values.

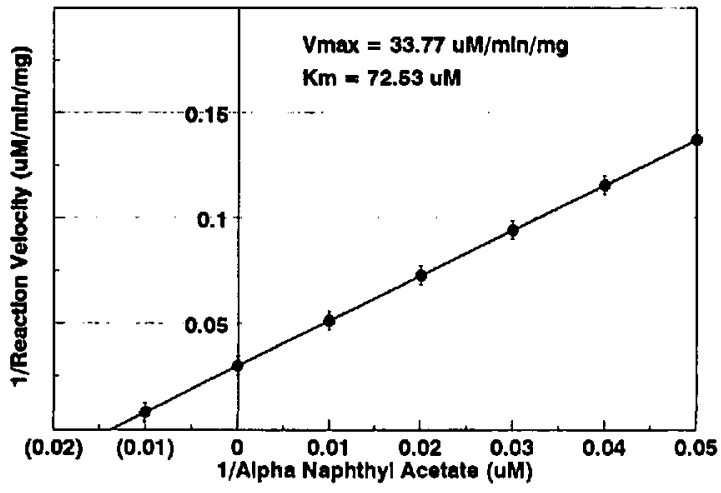

Fig. 3. Lineweaver-Burk plot of kinetics of general esterases from $\boldsymbol{R}$. flavipes workers determined using different concentrations of $\alpha$-naphthyl acetate (data point \pm SEM of three replications).

Effect of Temperature. The specific activity (activity $\pm \mathrm{SEM} ; \mathrm{n}=3$ ) of the termite general esterases increased with increasing temperature from $20^{\circ} \mathrm{C}(8.2 \pm 0.4)$ to $45^{\circ} \mathrm{C}(16.3 \pm 0.9)$ (Fig. 4B). Decreasing activities were observed from $45^{\circ} \mathrm{C}(16.3 \pm 0.9)$ to $60^{\circ} \mathrm{C}(7.5 \pm 0.3)$. Similarly, Ono et al. (1994) observed maximal specific activ-
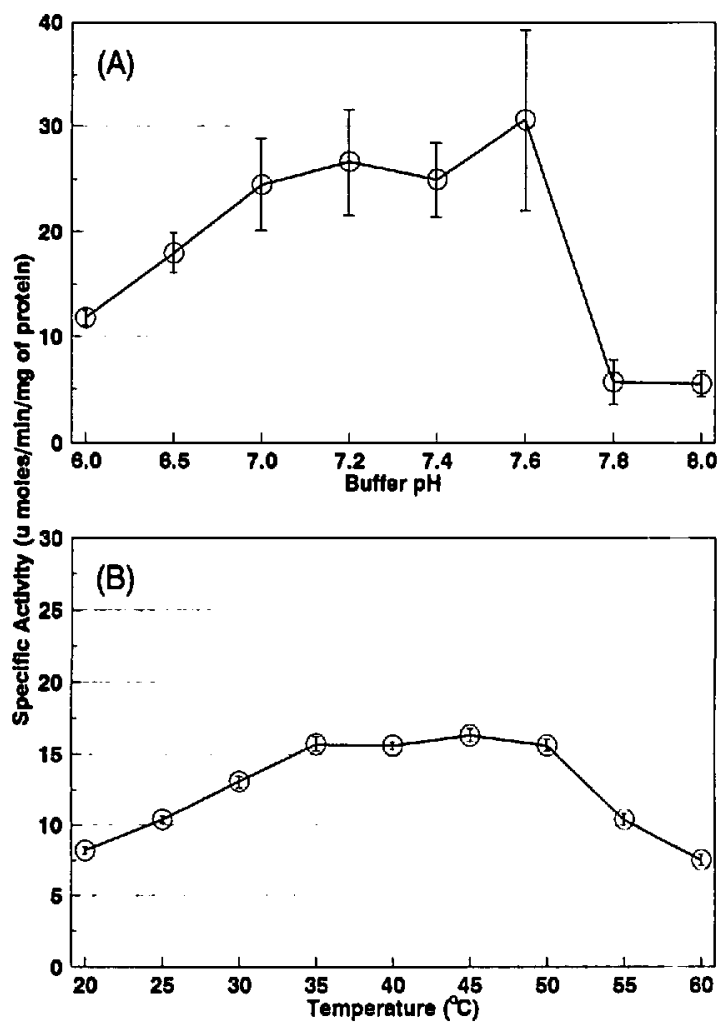

Fig. 4. Optimal conditions for assay of $R$. flavipes worker general esterases: (A) esterase activity and buffer $\mathrm{pH},(\mathrm{B})$ esterase activity and incubation temperature. Each point represents the mean \pm SEM of nine determinations. 


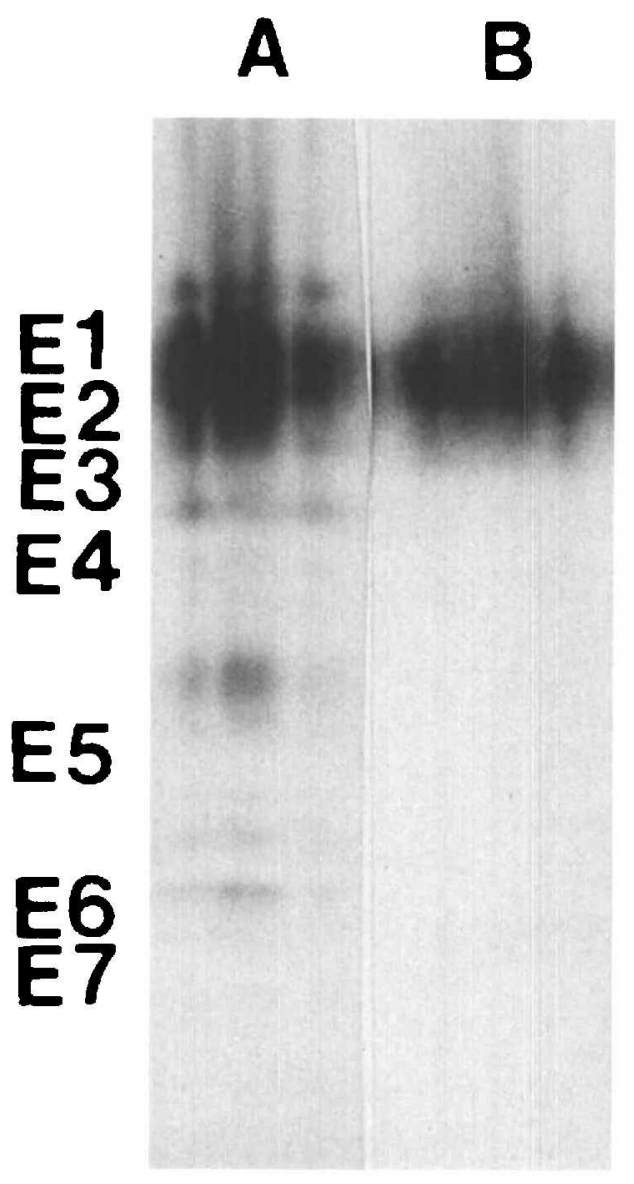

Fig. 5. Esterase isozymes separated by polyacrylamide gel electrophoresis $(A)$ Incubation in $\alpha$-naphthyl acetate and fast blue BB salt. (B) Incubation in physostigmine $\left(10^{5} M\right.$ ) before the addition of $\alpha$-naphthyl acetate and fast blue BB salt.

ities with incubation temperatures of $\approx 45^{\circ} \mathrm{C}$ in greenbugs. However, general esterases from a yeust symbiont of the cigarette beetle, Lasioderma serricome (F.), exhibited maximal esterase activity at $22^{\circ} \mathrm{C}$ and low specific activity at $40^{\circ} \mathrm{C}$ (Shen \& Dowd 1991).

Gel Electrophoresis. Nondenaturing PAGE of the termite worker homogenate stained with $\alpha$ niphthyl acetate indicated seven different esterase bunds (Fig. 5). These bands were labeled El-E7. E1 was the slowest migrating band and E7 the fastest. The E1-E4 bands stained strongly when compared with the remaining bands. Fewer esterase bands were detected by using this method in termite worker homogenate versus prepared homogenates of the German cockroach (10 bands) (Prabhakaran \& Kamble 1993).

Incubation of the polyacrylamide gels in the cholinesterase inhibitor physostigmine $\left(10^{-5} \mathrm{M}\right)$ before staining with $\alpha$-naphthyl acetate and fast
Table 1. Estimated molecular weights of general esterases from $R$. flavipes workers

\begin{tabular}{cc}
\hline \hline Esterase band & $\begin{array}{c}\text { Mol. wt } \\
\times 10^{3} \text { daltons }\end{array}$ \\
\hline E1 & 71.5 \\
E2 & 71.7 \\
E3 & 72.3 \\
E4 & 79.0 \\
E5 & 79.6 \\
E6 & 83.9 \\
E7 & 97.2 \\
\hline
\end{tabular}

blue $\mathrm{BB}$ salt resulted in reduced staining of bands E4, E5, E6, and E7 (Fig. 5B). These bands represent cholinesterase enzymes. When the gels were incubated in paraoxon $\left(10^{-6} \mathrm{M}\right.$ ) (an organophosphorous compound that inhibits cholinesterase and carboxylesterase enzymes) before incubation with $\alpha$-naphthyl acetate and fast blue BB salt, all seven esterase bands were completely inhibited. This result indicates that the remaining bands (E1, E2, and E3) can be classified as carboxylesterases.

Molecular Weight Determination. The molecular weights of each of the general esterases from the termite workers were estimated indirectly from protein standard retardation coefficients $\left(K_{\mathrm{R}}\right)$. The calculated molecular weights of the seven general esterase bands (E1-E7) ranged from 71.5 to 97.2 $\mathrm{kd}$ (Table 1). This molecular weight range is similar to esterase molecular weight estimations from both Blattella germanica (Prabhakaran \& Kamble 1994), and Culex pipiens L. (Callaghan et al. 1991).

These results indicate that $R$. flavipes workers have an active esterase system. The importance of esterases in the normal functioning of a termite colony is unknown. However, most insect esterases hydrolyze endogenous substances and play an important role in secondary metabolism. Termite esterases may also be involved in the detoxification of xenobiotics that are associated with the soil environment. Our study provides information necessary for further research on the involvement of esterases in physiological and endogenous metabolic functions in termites.

\section{Acknowledgments}

We thank Blair Siegfried and Steven Danielson (Department of Entomology, University of Nebraska, Lincoln) for their review of the manuscript. This is published as Paper No. 10793, Journal Series, Nebraska Agricultural Research Division and Contribution No. 868, Department of Entomology, Water Center/Environmental Programs-Institute of Agriculture and Natural Resources, University of Nebraska-Lincoln.

\section{References Cited}

Abdel-Aal, Y.A.I., M. A. Wolf, R. M. Roe \& E. P. Lampert. 1990. Aphid carboxylesterases: biochemical aspects and importance in the diagnosis of insecticide resistance. Pestic. Biochem. Physiol. 38: 255266. 
Almad, S., L. B. Brattsten, C. A. Mullin \& S. J. Yu. 1986. Enzymes involved in the metabolism of plant allelochemicals, pp. 73-151. In L. B. Brattsten \& S. Ahmad [eds.], Molecular aspects of insect-plant associations. Plenum, New York.

Aldridge, W. N. 1953. Serum esterases I. two types of esterase (A and B) hydrolyzing $\rho$-nitrophenyl acetate, propionate and a method for their determination. Biochem. J. 53: 110-117.

Asperen, K. van. 1962. A study of housefly esterases by means of a sensitive colorimetric method. J. Insect Physiol. 8: 401-416.

Augustinson, K. B. 1959. Electrophoretic studies on blood plasma esterases. Acta. Chem. Scand. 13: 571592.

1961. Multiple forms of esterase in vertebrate blood plasma. Ann. N.Y. Acad. Sci. 94: 844-870.

Beranek, A. P. 1974. Esterase variation and organophosphate resistance in populations of Aphis fabae and Myzus persicae. Entomol. Exp. and Appl. 17: 129-141.

Bradford, M. M. 1976. A rapid and sensitive method for the quantitation of microgram quantities of protein utilizing the principle of protein dye binding. Anal. Biochem. 72: 248-254.

Bryan, J. K. 1977. Molecular weights of protein multimers from polyacrylamide gel electrophoresis. Anal. Biochem. 78: 513-519.

Callaghan, A., C. A. Malcolm \& J. Hemingway. 1991. Biochemical studies of $\mathrm{A}$ and B carboxylesterases from organophosphate resistant strains of an Italian Culex pipiens (Diptera: Culicidae). Pestic. Biochem. Pliysiol. 41: 198-206.

Dauterman, W. C. 1976. Extramicrosomal metabolism of insecticides, pp. 149-176. In C. F. Wilkinson [ed.] Insecticide biochemistry and physiology. Plenum, New York.

Davis, B. J. 1964. Disc electrophoresis II. Method and application to human serum proteins. Ann. N.Y. Acad. Sci. 121: 404-427.

Davis, R. W. \& S. T. Kamble. 1994. Effects of low temperatures on survival of the eastem subterranean termite (Isoptera: Rhinotermitidae). J. Environ. Entomol. 23: 1211-1214

Eto, M. 1974. Organophosphorous pesticides: organic and biochemical chemistry. CRC, Cleveland.

Granovsky, T. A. 1983. Economic impact of termites. Pest Control 50: 14-19.

Junge W. 1984. Carboxylesterases, pp. 2-8. In H. U. Bergmeyer [ed.], Methods in enzymatic analysis, 3rd ed., vol. 4. Verlag, Miami.

Junge W. \& H. Kless. 1984. Arylesterases, pp. 8-14. In H. U. Bergmeyer [ed.], Methods in enzymatic analysis, 3rd ed., vol. 4. Verlag, Miami.

Kanble, S. T., R. E. Gold \& J. D. Rauscher. 1984. Distribution and economic impact of subterranean termites in Nebraska. Environmental Programs Report No. 9. University of Nebraska-Lincoln.

Krisch, K. 1971. Carboxylic ester hydrolysis, pp. 4385. In P. D. Boyer [ed.], The enzymes. Academic, New York.

Lineweaver, H. \& D. Burk. 1934. The determination of enzyme dissociation constants. J. Am. Chem. Soc. 56: 658-666.

Mampe, C. D. 1982. Termites, pp. 177-257. In A. Mallis [ed.], Handbook of pest control, 6th ed. Franzak \& Foster, Cleveland

Ono, M., J. S. Richman \& B. D. Siegfried. 1994. Characterization of general esterases from susceptible and parathion resistant strains of the greenbug (Homoptera: Aphididae). J. Econ. Entomol. 87: 14301436.

Pantelouris, E. M. \& A. Arnason. 1966. Ontogenesis of serum esterases in Mus musculus. J. Embryol. Exp. Morphol. 16: 55-64.

Prabhakaran, S. K. \& S. T. Kamble. 1993. Activity and electrophoretic characterization of esterases in insecticide resistant and susceptible strains of german cockroach Dictyoptera: Blattellidae). J. Econ. Entomol. 86: 1009-1013.

1994. Subcellular distribution and characterization of esterase isozymes from insecticide resistant and susceptible strains of German cockroach (Dictyoptera: Blattellidae). J. Econ. Entomol. 87: 541-545.

Shen, S. K. \& P. F. Dowd. 1991. 1-Naphthyl acetate esterase activity from cultures of the symbiont yeast of the cigarette beetle (Coleoptera: Anobiidae). J. Econ. Entomol. 84: 402-407.

Siegfried, B. D. \& J. G. Scott. 1992. Biochemical characterization of hydrolytic and oxidative enzymes in insecticide resistant and susceptible strains of the German cockroach (Dictyoptera: Blattellidae). J. Econ. Entomol. 85: 1092-1098.

Sivakumaran, S. \& Z B Mayo. 1991. Electrophoretic characterization of esterases in the greenbug, Schizaphis graminum (Rondani) (Homoptera: Aphididae). J. Kans. Entomol. Soc. 64: 357-362

Townson, H. 1972. Esterase polymorphism in Aetes aegypti: the genetics and $\mathrm{Km}$ values of electrophoretically heterogenous forms. Ann. Trop. Med. Parasitol. 66: 255-266.

Wheeler, G. C. \& J. Wheeler. 1963. The termites of North Dakota. J. Kans. Entomol. Soc. 36: 191-193.

Wilkinson, C. F. 1985. Biochemical nature of pesticide resistance in insects, pp. 311-325. In J. L. Hilton [ed.], BARC Symposium 8, Agricultural Chemicals of the Future. Rowman \& Allanheld, Totowa, N].

Received for publication 15 July 1994; accepted 17 January 1995. 